\title{
Making Changes: Application of an NSF-ADVANCE PAID Grant at a Pre- dominantly Undergraduate Institution (PUI)
}

\section{Dr. Theresa M. Vitolo, Gannon University}

Theresa M. Vitolo is an Associate Professor in the Computer and Information Science Department, Gannon University (Erie, PA). Teaching in systems-related fields since 1986, she joined the Computer and Information Science Department at Gannon University in 1999. In addition to teaching, she has worked as a systems analyst / programmer on a variety of systems development projects. Her academic background includes a B.S.E. in industrial engineering and a Ph.D. in information science; her industry experience includes systems analysis and cognitive science applications. She is one of the Principal Investigators on two NSF S-STEM and one NSF ADVANCE-PAID grants. With a life-long interest in technology and its potential for enhancing human capabilities, her research includes advances in analytics, motivated system energetics, and other topics relative to knowledge-intensive systems.

\section{Dr. Karinna M Vernaza, Gannon University}

Dr. Karinna Vernaza joined Gannon University in 2003, and she is currently a Professor in the Mechanical Engineering Department and Associate Dean of the College of Engineering and Business. She earned her Ph.D. and M.S. in mechanical engineering from the University of Notre Dame. Her B.S. is in Marine Systems Engineering from the U.S. Merchant Marine Academy. Her primary teaching responsibilities are in the solid mechanics and materials areas, including biomaterials. She was awarded the 2012 ASEE NCS Outstanding Teacher Award, 2013 Gannon University Distinguished Faculty Award and 2013-2014 Gannon University Faculty Award for Excellence in Service-Learning. Vernaza does research in the area of alternative fuels (biodiesel), engineering education (active learning techniques), and high-strain deformation of materials. She is currently the PI of an NSF S-STEM and ADVANCE-PAID grants. Dr. Vernaza has been a member of the ASEE NCS Board since 2013 holding vice-chair (2015-16) and director at-large (2013-15) positions.

\section{Dr. Lori D. Lindley, Gannon University}

Lori D. Lindley is an Associate Professor in the Department of Psychology and Counseling, and the Associate Dean of the College of Humanities, Education, and Social Sciences. She earned her B.A. in Psychology from the University of Notre Dame, and her M.S. and Ph.D. in Counseling Psychology from Iowa State University. She serves on the editorial boards of the Journal of Vocational Behavior and the Journal of Career Assessment. Her research is on women's career development, specifically self-efficacy and career barriers.

\section{Dr. Elisa M. Konieczko, Gannon University}

Elisa M. Konieczko, Professor of Biology at Gannon University, received her bachelor's degree from Gannon University and doctorate from the University of Pittsburgh School of Medicine. She is a CoPI on NSF ADVANCE Award HRD-1107015. She is a member of the American Association for Cell Biology and the American Anatomy Association.

\section{Dr. Weslene Tallmadge, Gannon University}

Dr. Tallmadge is Professor and Chair of the Department of Chemistry at Gannon University. 


\title{
Making Changes: Application of an NSF-ADVANCE PAID Grant at a Predominantly Undergraduate Institution (PUI)
}

\begin{abstract}
Gannon University received a five-year NSF ADVANCE-PAID award in 2011 to fund TRANSFORM, Teaching-Research-Advancement Network to Secure Female Faculty for Organizational Retention and Management. TRANSFORM initiatives aimed to increase the recruitment, retention, advancement, and leadership development of female faculty in STEM disciplines at a Master's L institution by adapting strategies proven successful at research universities. The grant has been operationalized through three strategies: (1) Dual Career Services aiming to provide employment opportunities to accompanying partners via the creation of a consortium and a website; (2) Research Initiation Awards supporting advancement and tenure needs by providing release time and funds to early-career female STEM faculty; and (3) Leadership Developments increasing education opportunities in the areas of leadership for faculty and administrators.

Strategy 1, Dual Career Services, focused on the recruitment and retention of STEM female faculty through the creation of a Dual Career Services program. Due to the regional profile of the area, a website, careersfor2.com, was established to serve not only the university but also local industry and other institutions as a regional professional job database, helping accompanying partners find suitable employment. To date, 287 jobs from 415 employers were advertised on this site. In 2015, Gannon University joined a regional Higher Education Recruitment Consortium (HERC) to sustain offering dual-career couples regional employment opportunities after the end of the grant period.

Strategy 2, the Research Initiation Award, provided six credits of release time from teaching and a stipend for research activities every year for two years for each awardee. The strategy sought to support junior female faculty at a teaching institution which also has a strong scholarship requirement for tenure and promotion. Through the support of the grant, the retention rate and promotion of female faculty in STEM disciplines was increased. By the end of the grant, six awardees will have benefitted from the grant. Metrics to measure the impact of this strategy are in place. The efforts will be continued through a university-wide, competitive release time program.

Strategy 3, Leadership Development, was to formalize professional development opportunities for faculty on the topic of leadership, previously not available at Gannon University. Using both internal experts and external consultants, workshops were planned for delivery in half-day segments throughout each academic year, culminating in a regional one-day-long seminar at the end of the academic year. Additionally, leadership development for department chairs and programs directors was planned to occur once each semester. Reactions to the workshops were generally positive, attendance has increased over the past four years, and sustained support of the workshops has been allocated by the administration through a collaboration between Academic Affairs and Human Resources.
\end{abstract}


Each strategy had its own challenges and successes, providing unique insight into the feasibility of converting a successful technique from a research institution into the structure of a predominantly undergraduate institution. For each strategy, the paper highlights the rationale for selecting the strategy, the objectives defined for realizing the strategy, the lessons learned from its implementation, and the culmination of the strategy in terms of sustainability and longterm influence upon the culture and climate of the university.

\section{Perspective driving the NSF effort}

Gannon University (Erie, PA) is a private, co-educational Catholic, Diocesan, comprehensive university offering over 70 undergraduate programs, 22 master's programs and 4 doctoral programs including online modalities. To teach approximately 4,416 undergraduate and graduate students, the university employs roughly 227 full-time faculty and over 165 adjunct faculty. Since the academic year 2010-2011, the University has added 15 new undergraduate and graduate majors or programs and 12 new full-time faculty positions while growing total enrollment by over $8 \%$. The academic structure is organized into three colleges: the College of Humanities, Education and Social Sciences (CHESS); the Morosky College of Health Professions and Sciences (MCHPS); and the College of Engineering and Business (CEB). Tenure-track/tenured faculty teach 24 credits per academic year and carry significant advising loads as expected in this student-centered environment.

Before 2003, tenure and promotions decisions were based on excellence in teaching and on service to the University, community, and professional organizations. With feedback from the University community and findings from the 2003 Middle States Evaluation, the Institutional Policy Manual (IPM) was revised to clarify tenure and promotion criteria. Included in this culture change was the establishment of a tenure clock for all tenure track faculty members and a stronger focus on scholarship. ${ }^{1}$ The Boyer Model of Scholarship was adopted and became an additional guideline for the tenure decision. ${ }^{2}$ While research or scholarship had been a component of some faculty members' portfolios, it occupied a small role compared to teaching and advising. However, now, promotion and tenure decisions have a tri-fold focus: teaching and advising, service, and scholarship.

\section{The data profile in 2009}

When the grant proposal was being conceptualized, data regarding faculty employment revealed the state of female faculty in STEM (biology, chemistry, computer and information science, mathematics, physics, electrical and computer engineering, environmental science and engineering, mechanical engineering, and psychology) and identified barriers at Gannon University for advancement, providing the basis for the request to the NSF ADVANCE program. Namely,

- Female faculty constituted a low percentage of the STEM faculty: $28.13 \%$ in 2009-2010; see Appendix, Table 6. 
- Female faculty were not advancing through the academic ranks as well as their male counterparts: 0\% of STEM professors were female in 2009-2010; see Appendix, Table 7.

- Institutional infrastructure and support needed to achieved the scholarship requirements was insufficient:

- Internal faculty research grants: $74 \%$ of requests were met in 2001-2002 while $21 \%$ of requests were met in 2009-2010

○ Internal faculty development grants: $64 \%$ met in $2001-2002$ versus $61 \%$ of request met in 2009-2010

○ No tenure-clock stop policy for any circumstance

- Lack of institutional leadership development opportunities

\section{Program overview}

The NSF ADVANCE Award \# 1107015 provided the funds $(\$ 385,919)$ to create the TRANSFORM (Teaching-Research-Advancement Network to Secure Female Faculty for Organizational Retention and Management) program which has the goal to increase the recruitment, retention, advancement, and leadership development of female faculty in STEM. Table 1 summarizes the program objectives and strategies. The strategies were operationalized as. $^{3}$

(1) Dual Career Services: Goal is to provide greater employment opportunities to accompanying partners. Anecdotal evidence from a focus group revealed that several STEM female faculty left Gannon University before rank or tenure decisions due to the inability of their partner to find employment within Northwest PA. The strategy was modeled after successful dual career offices implemented through ADVANCE grants at the University of Rhode Island, ${ }^{4,5}$ Grinnell College, ${ }^{6}$ University of Washington, ${ }^{7}$ University of Michigan, ${ }^{8}$ the University of Oregon, ${ }^{9}$ and elsewhere. ${ }^{10-11}$

(2) Research Initiation Awards: Goal is to provide resources for early- or mid- career female STEM faculty to support advancement in rank and tenure. The strategy drew on the success of ADVANCE programs at the University of Wisconsin, Madison, ${ }^{12}$ the University of Washington, ${ }^{13}$ and the University of Arizona. ${ }^{14}$ Both monetary funds and release time for research were provided in this strategy. Similar teaching loads were addressed by providing release time for research with an ADVANCE grant at the University of Puerto Rico at Humacao. ${ }^{15}$

(3) Leadership Development Seminars and Workshops: Goal is to increase the number of continuing education opportunities in the areas of leadership and to increase awareness of and to educate administrators on the issues affecting the success of STEM female faculty. Through the skill sets acquired female faculty will be prepared to pursue and/or serve in leadership positions within and outside the university. The strategy was modeled after the efforts of the following NSF IT-ADVANCE recipients: University of WisconsinMadison, ${ }^{16,17}$ University of Washington, ${ }^{18-20}$ Virginia Tech, ${ }^{21}$ University of Michigan, ${ }^{8}$ and Wayne State University. ${ }^{22}$ 
Table 1: Summary of Strategies and Their Goals

\begin{tabular}{|c|c|c|}
\hline \multicolumn{3}{|c|}{$\begin{array}{l}\text { Goal: To increase the recruitment, retention, advancement, and leadership development of } \\
\text { female faculty }\end{array}$} \\
\hline Goals & Objectives & Strategies \\
\hline $\begin{array}{l}\text { Recruitment / } \\
\text { Retention }\end{array}$ & $\begin{array}{l}\text { Recruit and retain female faculty in the } \\
\text { STEM disciplines }\end{array}$ & Dual Career Services \\
\hline $\begin{array}{l}\text { Retention / } \\
\text { Advancement }\end{array}$ & $\begin{array}{l}\text { Advance female faculty through the rank } \\
\text { and tenure process }\end{array}$ & Research Initiation Awards \\
\hline $\begin{array}{l}\text { Retention / } \\
\text { Advancement } \\
\text { /Leadership } \\
\end{array}$ & $\begin{array}{l}\text { Prepare female faculty to hold effective } \\
\text { leadership positions }\end{array}$ & \multirow{2}{*}{$\begin{array}{l}\text { Leadership Developments } \\
\circ \text { Leadership Series } \\
\circ \text { Chairs, Program Directors, } \\
\text { Administrators Series } \\
\circ \quad \text { One-day leadership seminar }\end{array}$} \\
\hline $\begin{array}{l}\text { Recruitment / } \\
\text { Retention / } \\
\text { Leadership }\end{array}$ & $\begin{array}{l}\text { Educate deans, department chairs, and } \\
\text { faculty leaders about issues affecting } \\
\text { female faculty }\end{array}$ & \\
\hline
\end{tabular}

\section{Strategy 1: Dual Career Services}

Fifteen years ago, Gannon University underwent several cultural changes under the leadership of its seventh president, Dr. Antoine Garibaldi, including a stronger focus on scholarship for all faculty members. The climate in many departments remained focused on teaching and service, without allowance for the increased emphasis on scholarship. This change adversely affected junior faculty seeking tenure or advancement in rank, many of whom were female. Most full professors were male and many achieved their promotion in rank before the culture change. Anecdotal evidence from focus groups revealed that several STEM female faculty left Gannon University before rank or tenure decisions due to the inability of their partner to find employment within a 180-mile radius of the university. This phenomena, colloquially termed "the two-body problem," is common to many academic institutions. ${ }^{23-25}$

Within the past 25 years, increased numbers of women are earning doctorates in the life sciences and engineering. ${ }^{26-28}$ Despite this fact, many academic institutions have trouble recruiting, retaining, and promoting women in STEM disciplines. ${ }^{23,26,29}$ This issue is further complicated by the fact that many female STEM faculty marry professional men who also seek careers in higher education. ${ }^{24} \mathrm{~A}$ common strategy to address this issue by many academic institutions is the creation of a dual career office or program. ${ }^{24,26,29}$

Strategy 1, Dual Career Services, focused on the recruitment and retention of STEM female faculty through the creation of a Dual Career Services program. The problem of hiring female faculty is further amplified at Gannon University due to the sparse industrial base and widely dispersed academic institutions within northwestern Pennsylvania. Dual Career offices, common at larger universities, are not present at any of the five local universities and colleges. 
Initially, the strategy focused on two activities: (1) the establishment of a Dual Career Consortium of Northwest Pennsylvania (DCCNP) and (2) the development of a website to connect partners and spouses of prospective university faculty hires with professional job openings within a 90-mile radius of Gannon University The successes and challenges encountered in implementing each of these activities will be addressed, in turn, as effort on the two activities underwent surges of linked progress and delays due to personnel and communication quagmires. What follows is a mini-case study describing the importance of the interpersonal relationships influencing an effort beyond any technical challenges to also be addressed.

The establishment and structure of the DCCNP was conceived to be a regional resource, benefitting other hiring sites that also faced placement problems for professional couples moving into the area. The effort was spearheaded by the human resource (HR) manager of Gannon University through his networks with regional HR units in local industries and academic institutions. The grant-team focusing on Strategy 1 consisted of two co-PIs from the NSF-ADVANCE grant team and the HR Director of Gannon University. This team, along with a vetted professional employment agency, conducted a search for a HR specialist to manage the consortium's beginnings and to forge connections with local industries. Some duties of the specialist were to contact, promote, and recruit HR managers from local universities, medical centers, corporations and businesses to become members of the consortium, and to build the employment-opportunity base of the DCCNP.

Processes for the DCCNP were defined to enable a shared responsibility for the consortium to foster. The recruited HR managers would form the core of the DCCNP, establishing guidelines for the consortium's mechanisms, meeting periodically as stewards of the DCCNP, and identifying mechanisms for future sustainability. The HR specialist would be the interface and manager of the consortium's interaction with the grant team, and with any other affiliates of the effort such as web development or hosting technical staff.

Most importantly, the DCCNP core members would be primary stakeholders in the specification and acceptance of the website supporting the DCCNP's access and communication points. Member institutions would be expected to post suitable, open professional opportunities to the site. Additionally, the significant others of prospective candidates for positions at institutions of the DCCNP would be given access to the site in order to review regional professional openings and could post resumes. In this way, each institution would contribute and could mutually benefit from these efforts to help bring future employees of the region. The ultimate goal was to strengthen the awareness of employment opportunities in the area, for all.

In an attempt to make some headway along the goals of the strategies while the HR specialist was starting to undertake the required duties of the position, the HR Director promoted the hiring of the web developer who would subsequently become the webmaster for the site. The strategy team envisioned a prototype site could be developed but would be adapted as more specification and features were defined by the core DCCNP members, thus using a development approach with the website. 
A web-development consultant was hired and tasked with the creation of a dual career website which would both advertise regional professional job openings and allow job seekers to post resumes in response to those job openings. In addition, resumes from job seekers could be posted in a searchable database on the website, such that employers could scan the database for suitable employees. The developer also could provide web hosting capabilities and services, making a seamless transition from development to deployment possible.

The initially hired HR specialist did not fulfill the needs of the position for various reasons from misrepresenting the DCCNP to inadequate commitment to the work-requirements of the position. The second specialist grasped the concept of the DCCNP, communicated it effectively to a wide-breadth of connections with the local business community, and aggressively promoted the consortium and the site. Within two months, over 100 institutions had been aligned and a group of six HR managers were identified as the core to discuss the dual career needs of the region. Eventually, this specialist reached out to over 400 employers (see Table 2).

In the meantime, the webmaster created the website: http://www.careersfor2.com, to serve not only the university but also local industry and other institutions as a regional professional job database, helping accompanying partners find suitable employment (see Figure 1). Its final processes and look-and-feel required acceptance by the consortium members.

Upon review several modifications to the website were communicated to the HR specialist, who also acted as liaison between any and all constituents. A major modification reflected how medium-to-large institutions receive and process applications. Through various communication and performance difficulties on the part of the webmaster required that, the HR specialist worked closely with the webmaster over the next18 months in order for a majority of the requested changes to be implemented. Unfortunately, these changes were not completed to specification or functioning.

To address these technical limitations and frustrations, a local technology group was hired to examine and to correct the architecture and functioning of the website. After six months, the group had resolved many technical short-comings and had renovated the site to be in accord with DCCNP specifications. Hence, in the third year of the grant, a functional website was up and running. To date, 287 jobs from 415 employers were advertised on this site (see Table 2).

Unfortunately, since the web development was delayed, stalled, and then re-ignited, the raison d'être for the DCCNP faded; the bonding of consortium members never occurred and the efforts of the group failed to coalesce. From local rivalries, to different business philosophies and processes, to "town-and-gown" disparities, to lack of a champion and driver, to momentum slow-down, the consortium failed to form a united front. For instance, one "town-and-gown" disparity arose as concerns that grant funding from a non-profit university would unfairly compete with private job placement among businesses. The strategy had envisioned a grassroots bonding to be grown, nurtured by commonly-shared needs and a commonly-shared solution, the consortium and the website. Unfortunately, this growth never occurred. 
Table 2: Activity Statistics of the DCCNP and Its Website

\begin{tabular}{|l|c|c|c|c|}
\hline \multicolumn{4}{|c|}{ Year 1- } \\
\end{tabular}

Not willing to eliminate the strategy and the progress made to date, the NSF-ADVANCE grant leadership team approached two groups within the Erie area to spearhead the responsibilities of the DCCNP. One group consisted of a consortium of HR managers dedicated to bringing diversity to corporate hires in the regional area; the other was the local chamber of commerce. These groups were identified because their missions dovetailed with the goals of the strategy. Through the next year, meetings and negotiations were conducted to define how the Dual Career Services strategy could transition into either of their organizations. Ultimately, however, both groups declined to incorporate the Dual Career Services strategy into their processes.

Continuing a multi-prong effort to transition the Dual Career Services strategy into a regional asset, the NSF-ADVANCE grant leadership team became award of the Higher Education 
Recruitment Consortium (HERC) (http://www.hercjobs.org/). Although Gannon University had been invited to join the inaugural membership of a regional HERC, funding was not available at that time. Since 2000, the initial HERC has grown to include 14 affiliated, regional HERCs operating throughout the United States. ${ }^{30}$ In 2015, Gannon University joined the Ohio/Western PA/West Virginia regional HERC (http://www.hercjobs.org/oh-western-pa-wv/index.html) to sustain offering dual-career couples regional employment opportunities now and after the end of the grant period.

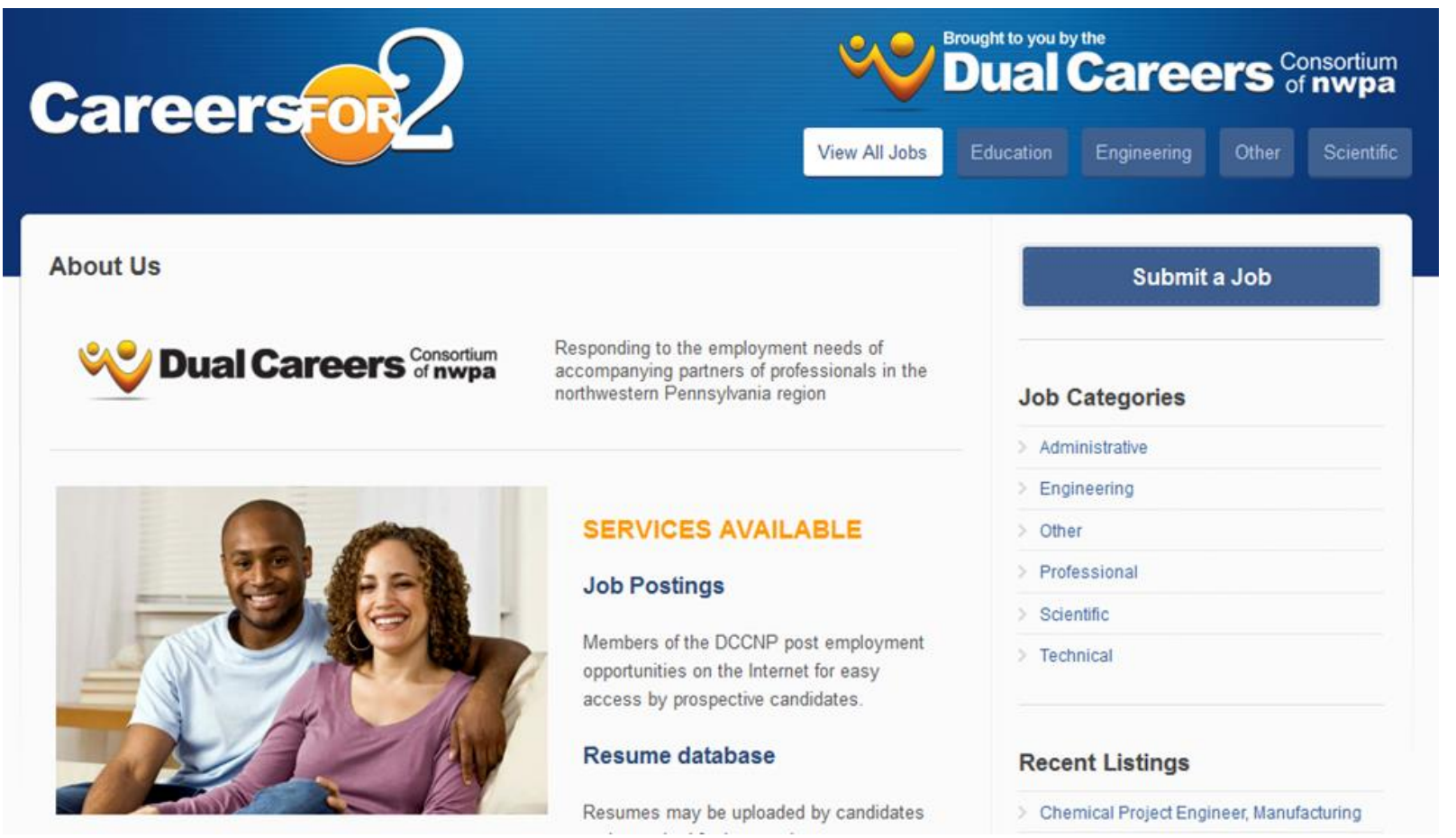

Figure 1: Dual Careers Website Home Page

\section{Strategy 1: Conclusion and lessons learned}

The implementation of a dual career program at Gannon University as envisioned and implemented through the grant, building upon a strategy successfully used by research universities, was not achieved. The strategy encountered significant regional resistance from corporate institutions and from the culture of the local environment. In addition, personnel, communication, and momentum issues weakened any progress made through the strategy's activities. The efforts of the strategy tried to transform a regional culture of disparate siloorganizations into a collaborative, distributed culture, but were ultimately unsuccessful. As of December 31, 2015, the website and consortium ceased.

Lessons learned in the course of the past five years are applicable to many initiatives bringing people, plans, and time together. 
- "Coming together is a beginning; keeping together is progress; working together is success." - Henry Ford

The goals of the strategy required a vision to be understood, shared, and embraced by multiple people from various organizations across many agendas. Throughout the years of the grant, success did occur when all parties worked together - on the common goal. When the focus of the common goal waned, the forward motion was stalled. At times, the loss of focus was due to lengthy durations between positive feedbacks, false expectations, and marginal improvements. Although the role of the HR specialist included maintaining the enthusiasm and focus of the diverse participants, in reality, without the core group coalescing into a consortium, the specialist was working with many, independent units, not a synthesized, larger unit.

- "The single biggest problem in communication is the illusion that it has taken place." George Bernard Shaw

Meetings, presentations, phone calls, emails, one-on-one sessions, documents - all were used as means of communication to try and address encountered difficulties. Repetitively, the co-PIs had to simply accept communication had not occurred.

- "The best laid plans of mice and men, often go awry." - Robert Burns Many of the risks encountered during the life of the strategy's implementation had been considered, their potential threat had mediation plans, and those plans had been enacted. Even so, the planning and efforts were insufficient to deal with the course-of-events.

The goals of the strategy have been sustained for the university, at least, through its recent association with the Ohio/Western PA/West Virginia regional HERC. All job candidates who are brought to campus for interviews are provided information about job opportunities for their significant other available through this regional HERC. In addition, job postings Gannon University are publicized on the HERC website, serving to attract faculty to the institution. The HR Department will oversee and finance the continuation of the membership in order to provide dual career services to its staffing portfolio.

\section{Strategy 2: Research Initiation Award}

Strategy 2, Research Initiation Award (RIA), has the goal to retain and promote female faculty in the STEM fields by providing release time and research funds for scholarship. High teaching loads of 12 credits per semester leave minimal time for laboratory and field research which could lead to scholarly products in the STEM fields. Prior to AY 2003, the scholarly requirement of faculty was significantly lower than it is at the present time. In addition, the ranks of associate and full professors have minimal female representation; at Gannon, tenure does not presume advancement in rank. Just as there has been increasing number of advanced degrees awarded to females across STEM disciplines, many of the recent hires affected by the increased emphasis on scholarship at Gannon University were female. Some STEM departments had no senior, female faculty to serve as mentors (see Table 7) and most full professors had received promotion when the university culture placed the majority of its emphasis on teaching and advising undergraduate 
students, not on scholarship. While this shift in emphasis promised to have a positive effect by improving the retention and success of students ${ }^{31}$ as well as the academic excellence of faculty, ${ }^{32}$ no adjustments were made in teaching load for the Gannon faculty. Time and money are important resources needed for scholarly productivity of faculty working primarily with undergraduate students. ${ }^{33}$

Through the RIA strategy, female STEM faculty at the assistant and associate professor rank could apply once each year for the release time and funding. One awardee was selected each year to receive the RIA which consists of three credits of release time per semester for two years and a total of $\$ 7500$ for research expenditures over those two years. Each year (2011-2014) about a dozen faculty qualified for the RIA. Qualified applicants included female faculty at the assistant or associate professor rank in the sciences, math, engineering or psychology. To date, four female STEM faculty members have received the RIA. Two additional female faculty have been supported with release time only.

To quantify the impact of receiving the RIA, a rubric based on the Boyer Model of Scholarship and the University's scholarship expectation was formulated by the grant Steering Committee. With the rubric, growth in research productivity is assessed and used to validate the impact of RIA support on the recipient's research goals. Evaluation through the use of the rubric provided relevant information to the administration to support increased institutional funding for release time for scholarship. Now, use of the rubric has been incorporated at the institutional level.

Results for the first awardee are shown in Table 3. The * is used to designate the years in which the awardee had the release time and funds from the RIA. Benchmark information is provided to show the impact of the release time on productivity.

Table 3: Productivity of Awardee \#1

\begin{tabular}{|c|c|c|c|c|c|c|}
\hline Category & $\begin{array}{l}\text { Points } \\
\text { for } \\
\text { Each } \\
\text { Item }\end{array}$ & $\begin{array}{c}\text { AY* } \\
\text { 13-14 } \\
\text { (points) }\end{array}$ & $\begin{array}{c}\text { AY* } \\
\text { 12-13 } \\
\text { (points) }\end{array}$ & $\begin{array}{c}\text { AY } \\
11-12 \\
\text { (points) }\end{array}$ & $\begin{array}{c}\text { AY } \\
\text { 10-11 } \\
\text { (points) }\end{array}$ & $\begin{array}{c}\text { AY } \\
09-10 \\
\text { (points) }\end{array}$ \\
\hline \multicolumn{7}{|c|}{ Professional, Peer-Reviewed \& Communicated } \\
\hline $\begin{array}{l}\text { External Grants received } \\
\text { larger than } \$ 50,000\end{array}$ & 5 & & & & & \\
\hline $\begin{array}{l}\text { Published International } \\
\text { Journal articles / Book } \\
\text { Chapters }\end{array}$ & 5 & & & & & \\
\hline $\begin{array}{l}\text { Published Articles; } \\
\text { National or International } \\
\text { Conference } \\
\text { Paper/Proceedings } \\
\end{array}$ & 4 & 12 & 4 & & & \\
\hline $\begin{array}{l}\text { External grants received } \\
\text { less than } \$ 50,000 \text { but } \\
\text { more than } \$ 20,000\end{array}$ & 4 & & & & & \\
\hline $\begin{array}{l}\text { External grants received } \\
\text { less than } \$ 20,000\end{array}$ & 3 & 6 & & 6 & & \\
\hline $\begin{array}{l}\text { Research/poster } \\
\text { presentations given at } \\
\text { meetings/conferences }\end{array}$ & 3 & 36 & 6 & & & \\
\hline
\end{tabular}




\begin{tabular}{|l|c|c|c|c|c|c|}
\hline \multicolumn{7}{|c|}{ Professional \& Communicated } \\
\hline Internal grants received & 1 & & 1 & 3 & 1 & 2 \\
\hline $\begin{array}{l}\text { Mentoring student } \\
\text { research grants }\end{array}$ & 1 & & 3 & 2 & 1 & 3 \\
\hline $\begin{array}{l}\text { Non peer-reviewed } \\
\text { (student or otherwise) } \\
\text { oral/poster presentations }\end{array}$ & 1 & 11 & 5 & 11 & 4 & 4 \\
\hline Total Points & & 65 & 19 & 22 & 6 & 9 \\
\hline$\%$ of work peer reviewed & & $83 \%$ & $53 \%$ & $27 \%$ & $0 \%$ & $0 \%$ \\
\hline
\end{tabular}

Additional benchmark data, Table 4, includes science faculty at the same rank who did not receive the RIA resources. Although the percentage of peer-reviewed work is similar, the total points earned in scholarship increased significantly for the awardee. The most significant impact of the awardee's work has been the incorporation of undergraduate students as co-researchers in her scholarship work. In the two years of work, eight undergraduate students made enough progress on projects with the faculty member to result in either professional publication or presentation.

Table 5 shows the results from the analysis of the second awardee. The engineering department does have masters' level students, and the faculty member typically taught nine credits each semester prior to the award rather than the twelve credits taught by science faculty. With the RIA, this faculty member increased collaborations with another researcher and graduate students, the number of publications, and the number of conferences attended. There was not a significant increase in percentage of peer-reviewed work, suggesting that increased release time for a faculty member who already has three credits of release time may not be beneficial for this institution.

Table 4: Comparison of Scores of RIA Recipient with Colleagues

\begin{tabular}{|l|c|c|c|c|c|c|}
\hline \multicolumn{1}{|c|}{$\begin{array}{c}\text { Total } \\
\text { Points }\end{array}$} & $\begin{array}{c}\mathrm{AY} * \\
13-14 \\
\text { (points) }\end{array}$ & $\begin{array}{c}\mathrm{AY} \\
\mathbf{1 2 - 1 3} \\
\text { (points) }\end{array}$ & $\begin{array}{c}\mathrm{AY} \\
\mathbf{1 1 - 1 2} \\
\text { (points) }\end{array}$ & $\begin{array}{c}\mathrm{AY} \\
\mathbf{1 0 - 1 1} \\
\text { (points) }\end{array}$ & $\begin{array}{c}\mathrm{AY} \\
\mathbf{0 9 - 1 0} \\
\text { (points) }\end{array}$ & $\begin{array}{c}\text { AY* } \\
\text { (points) }\end{array}$ \\
\hline $\begin{array}{l}\text { RIA } \\
\text { Awardee \# 1 }\end{array}$ & $65^{*}$ & $19^{*}$ & 22 & 6 & 9 & N/A \\
\hline $\begin{array}{l}\text { Colleague 1 } \\
\text { Without } \\
\text { Award }\end{array}$ & 0 & 16 & 14 & 13 & 5 & 8 \\
\hline $\begin{array}{l}\text { Colleague 2 } \\
\text { Without } \\
\text { Award }\end{array}$ & 22 & 25 & 13 & 4 & N/A & N/A \\
\hline
\end{tabular}

Table 5: Productivity of Awardee Two (Engineering)

\begin{tabular}{|c|c|c|c|c|c|c|}
\hline Category & $\begin{array}{l}\text { Points } \\
\text { for } \\
\text { Each } \\
\text { Item }\end{array}$ & $\begin{array}{c}\text { AY* } \\
\text { 13-14 } \\
\text { (points) }\end{array}$ & $\begin{array}{c}\text { AY* } \\
12-13 \\
\text { (points) }\end{array}$ & $\begin{array}{c}\text { AY } \\
\text { 11-12 } \\
\text { (points) }\end{array}$ & $\begin{array}{c}\text { AY } \\
10-11 \\
\text { (points) }\end{array}$ & $\begin{array}{c}\text { AY } \\
09-10 \\
\text { (points) }\end{array}$ \\
\hline \multicolumn{7}{|c|}{ Professional, Peer-reviewed \& Communicated } \\
\hline $\begin{array}{l}\text { External Grants received } \\
\text { larger than } \$ 50,000\end{array}$ & 5 & & & & & \\
\hline
\end{tabular}




\begin{tabular}{|c|c|c|c|c|c|c|}
\hline $\begin{array}{l}\text { Published International } \\
\text { Journal articles / Book } \\
\text { Chapters }\end{array}$ & 5 & 10 & & 5 & & \\
\hline $\begin{array}{l}\text { Published Articles; } \\
\text { National or International } \\
\text { Conference } \\
\text { Paper/Proceedings } \\
\end{array}$ & 4 & 20 & 12 & 4 & 12 & 8 \\
\hline $\begin{array}{l}\text { External grants received } \\
\text { less than } \$ 50,000 \text { but } \\
\text { more than } \$ 20,000\end{array}$ & 4 & & & & & \\
\hline $\begin{array}{l}\text { External grants received } \\
\text { less than } \$ 20,000\end{array}$ & 3 & & & & & \\
\hline $\begin{array}{l}\text { Research/poster } \\
\text { presentations given at } \\
\text { meetings/conferences }\end{array}$ & 3 & 6 & 6 & 6 & 12 & 8 \\
\hline \multicolumn{7}{|c|}{ Professional \& Communicated } \\
\hline Internal grants received & 1 & & & & & \\
\hline $\begin{array}{l}\text { Mentoring student } \\
\text { research grants }\end{array}$ & 1 & & & & & \\
\hline $\begin{array}{l}\text { Non peer-reviewed } \\
\text { oral/poster } \\
\text { presentations }\end{array}$ & 1 & & & & & \\
\hline Total Points & & 36 & 18 & 16 & 24 & 16 \\
\hline$\%$ of work peer reviewed & & $100 \%$ & $100 \%$ & $100 \%$ & $100 \%$ & $100 \%$ \\
\hline
\end{tabular}

Each RIA recipient submitted an end-of-year progress report which included research updates as well as individual comments regarding the impact of the award. Those comments focused on the importance of the release time to the research progress. Comments from the first three awardees regarding the release time include,

- "The RIA committee has done excellent job communicating with my Dean and my Chair to make sure I was truly awarded the release time. With the 3 credit hours released each semester, I finally had dedicated time for my research activities... The past two years was the most productive period since I joined Gannon in terms of paper publication, attending conferences, and collaborating with other colleagues and students... I wish every female faculty could have the same opportunity I had."

- "The release time has been very helpful in providing some time to focus on research. With this release time I was able to spend on average five to ten hours each week on research. Despite Gannon's high teaching load, I hope to increase this time to 10-15 hours each week during this next period."

- "Without a doubt, the release time provided through the RIA has allowed me to achieve many of the scholarship goals within my professional development plan. For example, I sought to submit and publish two manuscripts in 2013; I was successful. I was able to fully train undergraduate students, which allowed them to work more independently throughout the year, while being more productive. The time used for this not only supports my research goals, it fulfills my commitment to mentoring and training undergraduate students in research to provide them with valuable experience." 
Comments regarding the monetary funds include: "The funding provided me the independence to fully establish the methodology needed to pursue the questions related to the research objectives within my RIA proposal. When we encountered technical challenges, I had the funds necessary to adapt our protocols to continue to make forward progress." Each of the faculty recipients also highlighted the opportunity to establish collaborations during their award period.

\section{Strategy 2: Conclusion and changes realized}

The RIA demonstrated significant impact on number and quality of faculty publications, professional collaborations, undergraduate research portfolios and conference attendance. A rubric was developed specific to this institution's policies for promotion and tenure to analyze the increase in scholarship productivity. Due to the heightened awareness of the need to support scholarly productivity, the University has made positive changes. These include (1) a significant increase in the budget for internal faculty research and development grants; (2) a redistribution of release time credits across three colleges with preference to tenure-track faculty; (3) the implementation of a formal application process for awarding of scholarly release time across the entire university, and (4) a standardized rubric for the evaluation of faculty scholarship.

\section{Strategy 3: Leadership Development}

Strategy 3, Leadership Development, had the broad goal of increasing professional development opportunities for faculty. There is now a substantial body of literature on the importance of strategic and contextually-based leadership development. ${ }^{34-37}$ Specifically, the development of leaders cannot occur in isolation, but must occur in one's organizational context, which in this case is the university setting. Women often face additional challenges in leadership roles, such as being exposed to high levels of risk in leadership positions, and lacking the authority or support necessary to accomplish their goals. ${ }^{38}$

Before initiation of this strategy, professional development opportunities for faculty at Gannon University were limited to technology in teaching workshops offered through the Center for Excellence in Teaching and Learning (CETL). Therefore, creation of a leadership development program required the utilization of successful models at other universities. ADVANCE programs at the University of Michigan, ${ }^{8}$ the University of Wisconsin-Madison, ${ }^{17}$ and the University of Washington ${ }^{19}$ addressed leadership development from a highly contextual and multifaceted perspective. An effective focus on the development of department chairs can also be seen in the ADVANCE program at the University of Wisconsin-Madison. ${ }^{16}$ Based on these varied successful models, the Leadership Development strategy at Gannon University was designed to broaden professional development opportunities for faculty and was delivered through three activities.

Activity 1, Leadership Development Training, aimed to develop a curriculum to prepare all faculty for leadership roles. An initial list of topics was generated from focus groups and programming that had been offered at other institutions that had a similar professional 
development series. Later, topics were generated from feedback on sessions and responses to written evaluation questions from the workshops. Workshop topics that have been offered during 2012-2016 include:

- Leadership and self-knowledge

- Team building and delegation

- Least preferred coworker

- Negotiations

- $\quad$ Present like a pro... and get results!

- Goal setting and 360 feedback
- Work life balance

- Strength-based leadership

- Power distance

- Self-awareness and selfmanagement

- Social awareness and relationship management

- Emotional intelligence
- Conflict resolution and problem-solving strategies

- Embracing change and overcoming resistance

- The architecture of a positive work environment
- Communicate with impact

- How to get people to "buy into" change

- Project management

- Grant writing

- Implicit bias

Three half-day workshops were offered each academic semester. Slightly over half of the workshops in Activity 1 have been delivered by external consultants hired by the Strategy 3 coordination team. The team carefully selected consultants and put forth considerable effort in educating the consultants about the culture of the academic setting, and of Gannon University in particular, to ensure the relevance and applicability of the material to participants. The remainder of the workshops have been delivered by faculty and staff at Gannon University, occasionally with incorporation of a webinar.

All three colleges in the university were represented among participants in the leadership workshops, with a tendency toward slightly higher percentages of faculty from the College of Engineering and Business participating. One notable trend throughout the four years of the professional development offerings was an increase in participation by staff members at the university as marketing approaches evolved. When programming began, a substantial majority of participants were faculty, but by 2015 approximately half the participants were staff members from various offices throughout the university (see Fig. 2). Therefore, one of the significant lessons learned was an interest and need for professional development programming for staff at the university.

Feedback on each leadership workshop was sought through the completion of post-workshop questionnaires. Evaluation of the workshops tended to be generally positive, and tended to value the balance between formal presentation and activities or group involvement. Participants routinely stated that they would be able to apply content from the workshop to their current job roles. Some representative comments include:

- "The subject matter was appropriate and of high interest to me."

- "I learned suggestions that will make my projects run better."

- "It is nice to see other members of the university and how we can work together."

- "There were lots of notes and information that I can immediately and easily apply to my role."

- "I enjoyed every part of the workshop and I know what I learned will be beneficial in my future."

- "This was, by far, the most informative workshop I have ever attended!" 


\section{Strategy 3, Activity 1 Leadership Development Training}

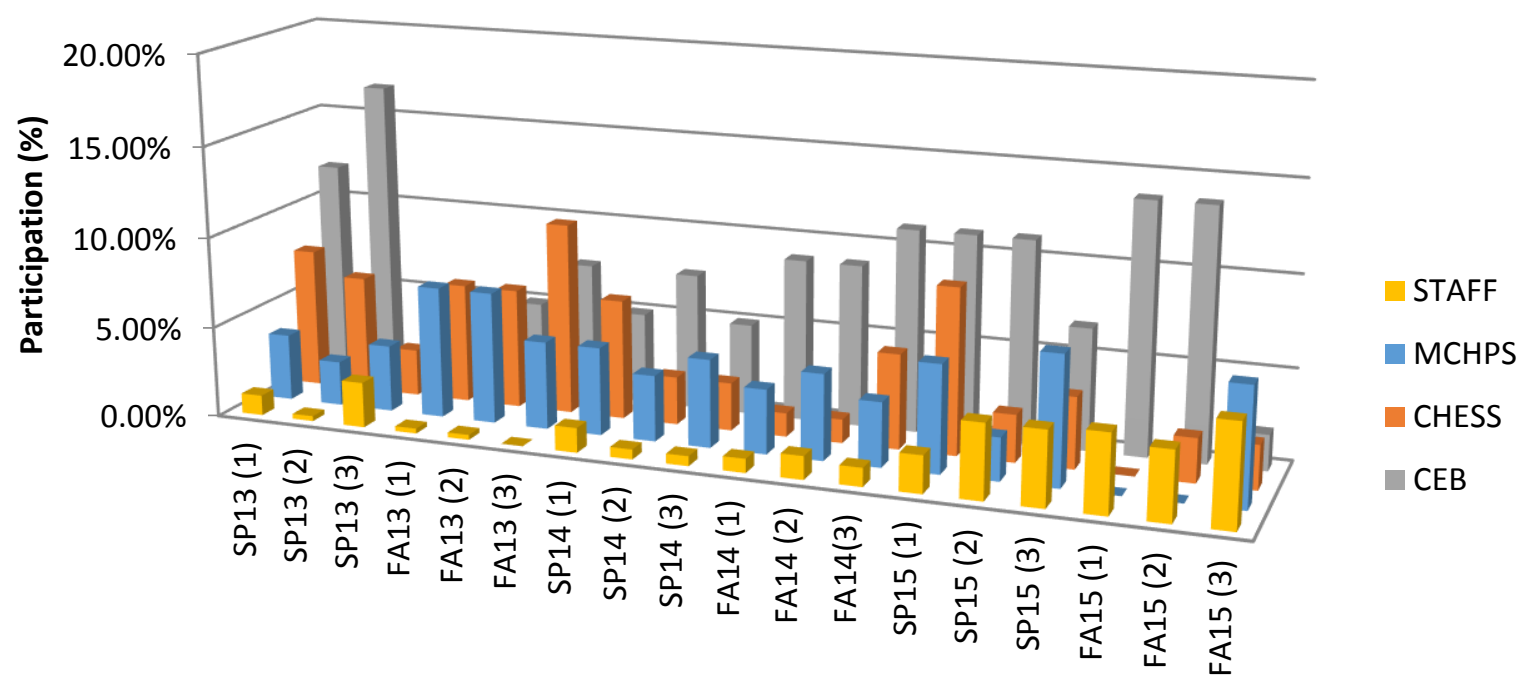

Semester, Year and Number of event (SP = Spring, FA = Fall)

Figure 2: 2013-2015 Participation in Leadership Series by College. Three events per semester. Note: Adjunct participation is insignificant.

Participants often stated that they would like to have the opportunity to participate in workshops such as these in their own professional context, i.e., in their division or department. Another common suggestion requested the material to be presented in terms of data and processes specific to Gannon. The feedback enhances plans to design future resources and offerings..

Activity 2, Leaders' Forum for Climate Change, specifically targeted department chairs, program directors, and academic deans. However, if a transition in roles was anticipated, faculty who might become department chair or program director in the near future were also encouraged to attend. This activity consisted of one half-day workshop each academic semester. Workshop topics during 2012-2015 included:

- Academic gender equality

- Effective and fair evaluations

- Understanding and avoiding legal issues (Offered twice)

- Budgeting and getting the resources your department needs
- Implicit bias in hiring

- Dealing with difficult people

- Conducting evaluations and providing feedback

- Program outcomes assessment 
As with Activity 1, all colleges were represented among the participations in the workshops. At times, differences in responsibilities across departments and levels of administration became an issue, but in general the feedback was positive. Additionally, requests were made for "assistance with moving into a supervisory role (learning to be a director, dean, etc.)" Some representative comments include:

- "Content was very relevant."

- "Guest speakers were diverse and could talk on several aspects of the topic."

- "Knowing that others encounter similar situations and hearing how they try to respond is useful."

- "I especially liked the fact that we were not overloaded with information - the small discussions were valuable and the panel discussion was excellent."

- "I seriously enjoyed this workshop and found the context very meaningful and beneficial. In brief, great job!"

Activity 3, Regional Leadership Symposium, was a one-day culmination of the leadership workshops provided throughout the academic year. Held during the week after the conclusion of the spring semester, a keynote speaker was brought to address issues for leaders in higher education, with emphasis on a specific theme. Unlike Activities 1 and 2, the Regional Leadership Symposium was advertised to faculty and other professionals in the Lake Erie tristate area rather than having entirely an internal audience.

The regional leadership symposium was not held after the first academic year of the grant, so the inaugural event was in May 2014. A national speaker was brought to deliver a workshop on the topic of Transformational Leadership. Seventy-seven participants attended the event; 65 were Gannon University employees and 12 were regional attendees. For the second annual event, held in May 2015, attendance nearly doubled with 114 participants. The topic for that event was Project Management, and follow-up topics were offered through the Leadership Series (Activity 1) during the 2015-2016 academic year. Feedback from participants indicated material which was immediately applicable to their work was especially appreciated, as well as connection to the Leadership Series offered during the academic year. The topic of the May 2016 event will be "Managing and Leading Change".

\section{Strategy 3: Conclusion and needs clarified}

As the funding period draws to a close, efforts are being made to ensure the continuation of these valuable professional development opportunities. There is a clear need for leadership development for faculty and staff at Gannon University as well as structured guidance for department chairs and program directors, roles that may change frequently and are preceded by no formal training. Fortunately, the university has recognized the value of the programming funded through the grant, and commitments have been made toward for sustainability. Activity 1 will be funded through Human Resources, Academic Affairs and CETL, and will be administered by a team of faculty and through the three Dean's Offices. Activity 2 will be funded and administered through the office of the Vice President for Academic Affairs, and will likely consist of a set curriculum of topics viewed as necessary for the orientation of new chairs 
and program directors. Finally, Activity 3 has been recommended to be combined strategically with a regional teaching and technology symposium currently offered through CETL, also at the conclusion of the academic year. Combining the events in this way will hopefully increase participation and impact; by focusing efforts into a single event, faculty may be more likely to attend at this busy time of the year.

\section{Long-term changes effected}

In conclusion, many institutional changes have occurred since the beginning of the NSF ADVANCE-PAID grant in 2011, namely,

- Dual career support for all current and perspective employees

- Increase in the number of female STEM full professors: 0\% in 2009-2010 versus 5.5\% in 2014-2015

- Formalization of the release time process across the university:

○ In 2009-2010 no formal, university-wide process existed although twenty-six faculty in the School of Engineering and Computer Science regularly received three credits per semester. In 2014, a formal process was established for all faculty. By 20152016, 40 requests were received, 39 awards granted, and 199 release credits realized.

- Changes in Faculty Research Grant and Faculty Development Grant processes

- Increased funding for Faculty Research Grant

○ Between 2002-2010, the average internal research monies pool was $\$ 20,000$. In 2014 , the university increased the research pool to $\$ 95,800$ with $49 \%$ of requests funded.

- Increased funding for Faculty Development Grant

○ In 2001-2002, the internal faculty development pool was $\$ 22,265$ with $63.71 \%$ of the requests funded. In 2009-2010, the funds were increased to $\$ 60,132$ and $61.43 \%$ of the requests were funded. In 2014-2015, the funds were increased to $\$ 104.486$ with $83.04 \%$ of the requests funded.

- Increased in awareness in leadership aspirations

○ In 2004-2005, 20\% of the STEM chairs/program directors were female; in 2014$2015,33 \%$ are female.

- Definitions and extensions of leadership programming for faculty and staff

All-in-all, positive impacts have been made in the institution and the culture. The ADVANCE funding provided the impetus for Gannon University to examine its processes, to drive its culture forward, and to realize positive changes. 


\section{Acknowledgement}

This work is based upon work supported by the National Science Foundation under Grant No. 1107015. Any opinions, findings, and conclusions or recommendations expressed in this material are those of the authors and do not necessarily reflect the views of the National Science Foundation.

\section{References}

[1] Gannon University, "Institutional Policy Manual: Sections 4.5-4.7," (2015-2016). [Online]. Available: http://my. University.edu.

[2] E. L. Boyer, Scholarship Reconsidered: Priorities of the Professoriate. Princeton, NJ: Carnegie Foundation for the Advancement of Teaching, 1990.

[3] K. M. Vernaza, T. M. Vitolo, E. M. Konieczko, and W. Tallmadge, (2011, September 1). TRANSFORM: Teaching Research Advancement Network to Secure Female Faculty for Organizational Retention and Management. NSF: HRD \#1107015.

[4] University of Rhode Island. (2007). Dual Career Research Subcommittee findings. [Online]. Available: www.uri.edu/advance/files/pdf/papers\%20\&\%20persentations/AWPpowerpointdualcareer.pdf. Accessed: October 12, 2010.

[5] B. Silver, F. Boudreaux-Bartels, H. Mederer, L. Pasquerella, J. Peckham,, M. Rivero-Hudec, and K. Wishner, "A warmer climate for women in engineering at the University of Rhode Island," presented at the American Soc. Eng. Edu. 2006 Annu. Conf. Proc., Chicago, IL, June 18-21, 2006.

[6] Grinnell College. (2004). Final report to the Grinnell College Board of Trustees: Strategic planning for Grinnell College. [Online]. Available: http://www.grinnell.edu/files/downloads/StrategicPlanning_0.pdf. Accessed: October 12, 2010.

[7] University of Washington. (2006). Recommendations to chairs for facilitating dual career hires. [Online]. Available: www.engr.washington.edu/advance/resources/dual_career_hires.html. Accessed: October 12, 2010.

[8] University of Michigan. (2010). ADVANCE program. [Online]. Available: http://www.advance.rackham.umich.edu/GSE-_Faculty_Recruitment_Retention.pdf. Accessed: October 10, 2010.

[9] University of Oregon. (2010). Dual career guidelines. [Online]. Available: http://ups.uoregon.edu/content/dualcareer-guidelines. Accessed: October 12, 2010.

[10] A. Higginbotham, (September, 2010). Recommendations on partner accommodation and dual career appointments. Report of the subcommittee of the Committee on Women in the Academic Profession. [Online]. Available: http://www.aaup.org/NR/rdonlyres/E8B6FE51-3765-4528-AC4F874C8ECDB7D9/0/PartnerandDualCareerAppointments.pdf. Accessed: October 6, 2010.

[11] S. Jaschik, "Doing 'dual career' right." Inside Higher Ed., Sept. 1, 2010. [Online]. Available: http://www.insidehighered.com/news/2010/09/01/dual. Accessed: October 6, 2010. 
[12] M. Pribbenow, M. and D. Benting, (2004). WISELI's life cycle research grant program: formative and summative evaluation. [Online]. Available: http://wiseli.engr.wisc.edu/docs/EvalReport_LCRGFinal_ 2004.pdf. Accessed: October 6, 2010.

[13] S. E. Lange, E. A. Riskin, S. G. Brainard, and D. D. Denton, (2003). Implementing a transitional support program. [Online]. Available: https://journals.psu.edu/wepan/article/view/58306/57994. Accessed: April 18, 2016.

[14] A. E. Estes, (2008). Successful Science collaboration and Mentoring. [Online]. Available:

https://web.archive.org/web/20100701165449/http://www.advance.arizona.edu/newsletters/ADVANCE_Vol2Is sue1.pdf. Accessed: April 18, 2016.

[15] I. Ramos, and S. Benitez, "Advancing women science faculty in a small, hispanic undergraduate institution" in Transforming Science and Engineering: Advancing Academic Women, A. J. Stewart, J. E. Malley, and D. LaVaqu-Manty, Eds., Ann Arbor: University of Michigan Press, 2007, pp. 243-261.

[16] University of Wisconsin-Madison. (2009). Enhancing department climate: A Chair's Role ${ }^{\circledR}$ : A workshop series for department chairs. [Online]. Available: http://wiseli.engr.wisc.edu/climate.php. Accessed: October 10, 2010.

[17] University of Wisconsin-Madison. (2009). Leadership excellence for academic diversity: National leadership workshops series. [Online]. Available: http://wiseli.engr.wisc.edu/uwpgms/leadership-development.php. Accessed: October 10, 2010.

[18] University of Washington. (2007). Results from and impact of the University of Washington ADVANCE Center for Institutional Change. [Online]. Available: http://www.engr.washington.edu/advance/resources/ UW_ADVANCE_results_overview.pdf. Accessed: October 10, 2010.

[19] University of Washington. (2009). ADVANCE resources. [Online.] Available: http://www.engr.washington.edu/advance/resources/\#other_resources. Accessed: October 10, 2010.

[20] J. W. Yen, S. E. Lange, D. D. Denton and E. A. Riskin, "Leadership development workshops for department chairs," in 2004 WEPAN Conf., Albuquerque, NM, June 6-9, 2004. [Online]. Available: http:// www.engr.washington.edu/advance/workshops/WEPAN_paper_UW_Leadership_Workshop.pdf. Accessed: October 10, 2010.

[21] Virginia Polytechnic Institute and State University. (2003). ADVANCE for the Advancement of Women in Science and Engineering Careers. [Online]. Available: http://www.portal.advance.vt.edu/. Accessed: October 10, 2010.

[22] Wayne State University. (2007). ESCALATE: Engineering and science careers in academia: Learning from ADVANCE and translating effectively. [Online]. Available: http://www.escalate.wayne.edu/. Accessed: October 12, 2010.

[23] C. K. Holahan, and L. A. Gilbert. "Conflict between major life roles: Women and men in dual career couples," Human Relations, vol. 32, no. 6, pp. 451-467, 1979.

[24] L. E. Wolf-Wendel, S. B. Twombly, and S. Rice, "Dual-career couples: Keeping them together," J. Higher Edu., vol.71, no. 3, pp. 291-32, 2000.

[25] L. Wolf-Wendel, S. B. Twombly, and S. Rice, The Two-Body Problem: Dual-Career-Couple Hiring Practices In Higher Education. Baltimore: JHU Press, 2004.

[26] C. A. Trower, "A new generation of faculty: Similar core values in a different world," Peer Rev., vol. 12, no. 3, pp. 27-30, 2010. 
[27] S. Sandberg, Lean In: Women, Work, and the Will to Lead. New York: Random House, 2013.

[28] M. Klawe, T. Whitney, and C. Simard, "Women in computing---take," Commun. ACM, vol. 52, no. s, pp. 68-76, 2009.

[29] L. L. Schiebinger, A. D. Henderson, and S. K. Gilmartin, "Dual-career academic couples: What universities need to know," Michelle R. Clayman Institute for Gender Research, Stanford University, 2008.

[30] HERC. (2000-2015). The Higher Education Recruitment Consortium. [Online]. Available: http://www.hercjobs. org/about_herc/vision_mission_programs_history/.

[31] S. R. Gregerman, (2008). "The role of undergraduate research in student retention, academic engagement, and the pursuit of graduate education," Promising Practice in STEM Education, National Academy of Science. [Online]. Available: http://sites.nationalacademies.org/cs/groups/dbassesite/documents/webpage/dbasse_ 072631.pdf. Accessed: April 15, 2016.

[32] M. P. Doyle, (Ed.), Academic Excellence: The Role of Research in the Physical Sciences at Undergraduate Institutions. (2000) Research Corporation, Tucson, AZ. [Online]. Available: http://files.eric.ed.gov/fulltext/ ED477576.pdf. Accessed: April 15, 2016.

[33] Undergraduate Research Summit, Bates College, Enhancing Research in the Chemical Sciences at Predominately Undergraduate Institutions. A Report from the Undergraduate Research Summit, Bates College, Lewiston ME. August 2-4, 2003 [Online.] Available: http://www.cur.org/assets/1/7/Summit_Report.pdf. Accessed: April 15, 2016.

[34] D. V. Day, J. W. Fleenor, L. E. Atwater, R. E. Sturm, and R. A. McKee, "Advances in leader and leadership development: A review of 25 years of research and theory," Leadership Quart., vol. 25, pp. 63-82, 2013.

[35] D. S. DeRue and C. G. Myers, "Leadership development: A review and agenda for future research," in The Oxford Handbook of Leadership and Organizations, D. V. Day, Ed. Oxford: Oxford University Press, pp. 833$855,2014$.

[36] J. E. Dinh, R. G. Lord, W. L. Gardner, J. D. Meuser, R. C. Liden, and J. Hu, "Leadership theory and research in the new millennium: Current theoretical trends and changing perspectives," Leadership Quart., vol. 26, pp. 3662, 2014.

[37] E. E. Hornsby, H. A. Morrow-Jones, and D. A. Ballam, "Leadership development for faulty women at The Ohio State University: The President and Provost's Leadership Institute," Advances in Developing Human Resources, vol. 14, no. 1, pp. 96-112, 2012.

[38] C. Glass and A. Cook, "Leading at the top: Understanding women's challenges above the glass ceiling," Leadership Quart., vol. 27, pp. 51-63, 2015. 


\section{Appendix}

Table 6: Percentage of Female Faculty in STEM-Related Administrative Units at Gannon University, 2009-2014

\begin{tabular}{lcccccc}
\multicolumn{1}{c}{ Program/Department } & $\mathbf{2 0 0 9 - 1 0}$ & $\mathbf{2 0 1 0 - 1 1}$ & $\mathbf{2 0 1 1 - 1 2}$ & $\mathbf{2 0 1 2 - 1 3}$ & $\mathbf{2 0 1 3 - 1 4}$ & $\mathbf{2 0 1 4 - 1 5}$ \\
\hline Bioinformatics Department & $0.00 \%$ & $0.00 \%$ & $0.00 \%$ & $0.00 \%$ & $0.00 \%$ & $0.00 \%$ \\
\hline Biology Department & $28.57 \%$ & $35.71 \%$ & $38.46 \%$ & $50.00 \%$ & $52.94 \%$ & $50.00 \%$ \\
\hline Bio-Medical Engineering & - & - & - & - & $0.00 \%$ & $50.00 \%$ \\
\hline Chemistry Department & $25.00 \%$ & $37.50 \%$ & $37.50 \%$ & $33.33 \%$ & $44.44 \%$ & $50.00 \%$ \\
\hline Computer \& Information Science & $60.00 \%$ & $60.00 \%$ & $60.00 \%$ & $60.00 \%$ & $60.00 \%$ & $40.00 \%$ \\
\hline Electrical \& Computer Engr. & $25.00 \%$ & $25.00 \%$ & $25.00 \%$ & $25.00 \%$ & $25.00 \%$ & $22.22 \%$ \\
\hline Environmental Science Dept. & $33.33 \%$ & $50.00 \%$ & $33.33 \%$ & $33.33 \%$ & $33.33 \%$ & $33.33 \%$ \\
\hline Mathematics Department & $28.57 \%$ & $28.57 \%$ & $28.57 \%$ & $28.57 \%$ & $28.57 \%$ & $33.33 \%$ \\
\hline Mechanical Engineering & $14.29 \%$ & $14.29 \%$ & $14.29 \%$ & $14.29 \%$ & $16.67 \%$ & $11.11 \%$ \\
\hline Physics Department & $0.00 \%$ & $0.00 \%$ & $0.00 \%$ & $0.00 \%$ & $0.00 \%$ & $0.00 \%$ \\
\hline Psychology Program & $50.00 \%$ & $55.56 \%$ & $50.00 \%$ & $44.44 \%$ & $40.00 \%$ & $33.33 \%$ \\
\hline Software Engineering & $0.00 \%$ & $0.00 \%$ & $0.00 \%$ & $0.00 \%$ & $0.00 \%$ & $0.00 \%$ \\
\hline STEM TOTAL & $\mathbf{2 8 . 1 3 \%}$ & $\mathbf{3 3 . 3 3 \%}$ & $\mathbf{3 2 . 3 1 \%}$ & $\mathbf{3 4 . 2 9 \%}$ & $\mathbf{3 6 . 1 1 \%}$ & $\mathbf{3 2 . 8 8 \%}$ \\
\hline UNIVERSITY TOTAL & $\mathbf{4 5 . 0 0 \%}$ & $\mathbf{4 6 . 9 4 \%}$ & $\mathbf{4 6 . 1 9 \%}$ & $\mathbf{4 5 . 8 1 \%}$ & $\mathbf{4 5 . 7 3 \%}$ & $\mathbf{4 5 . 4 1 \%}$ \\
\hline
\end{tabular}

Table 7: Gender Distribution across Academic Ranks within STEM Departments, 2009-2014

\begin{tabular}{|l|c|c|c|c|c|c|}
\hline \multirow{2}{*}{ Year } & \multicolumn{2}{c}{ Professor } & \multicolumn{2}{c|}{ Associate } & \multicolumn{2}{c|}{ Assistant } \\
\hline & Male & Female & Male & Female & Male & Female \\
\hline $\mathbf{2 0 0 9 - 2 0 1 0}$ & $18.8 \%$ & $\mathbf{0 . 0 \%}$ & $23.4 \%$ & $12.5 \%$ & $25.0 \%$ & $12.5 \%$ \\
\hline $\mathbf{2 0 1 0 - 2 0 1 1}$ & $18.2 \%$ & $\mathbf{0 . 0 \%}$ & $24.2 \%$ & $15.2 \%$ & $19.7 \%$ & $15.2 \%$ \\
\hline $\mathbf{2 0 1 1 - 2 0 1 2}$ & $20.0 \%$ & $\mathbf{3 . 1 \%}$ & $24.6 \%$ & $10.8 \%$ & $18.5 \%$ & $16.9 \%$ \\
\hline $\mathbf{2 0 1 2 - 2 0 1 3}$ & $22.9 \%$ & $\mathbf{2 . 9 \%}$ & $18.6 \%$ & $11.4 \%$ & $20.0 \%$ & $15.7 \%$ \\
\hline $\mathbf{2 0 1 3 - 2 0 1 4}$ & $23.6 \%$ & $\mathbf{2 . 8 \%}$ & $18.1 \%$ & $9.7 \%$ & $18.1 \%$ & $19.4 \%$ \\
\hline $\mathbf{2 0 1 4 - 2 0 1 5}$ & $20.5 \%$ & $\mathbf{5 . 5 \%}$ & $17.8 \%$ & $6.8 \%$ & $19.2 \%$ & $19.2 \%$ \\
\hline
\end{tabular}

*instructor rank not included 